\title{
Faktor Risiko Sepsis Awitan Dini
}

\author{
Rocky Wilar, Ellen Kumalasari, Diana Yuliani Suryanto, Stefanus Gunawan \\ Bagian Ilmu Kesehatan Anak Fakultas Kedokteran Universitas Sam Ratulangi / RS Prof. \\ Dr.R.D.Kandou, Manado
}

\begin{abstract}
Latar belakang. Insiden sepsis neonatorum masih tinggi, oleh karena itu diperlukan perhatian khusus pada deteksi dini untuk tata laksana lebih dini.

Tujuan. Mengetahui faktor risiko potensial yang menyebabkan sepsis awitan dini.

Metode. Studi retrospektif kohort dilaksanakan pada Bagian Neonatologi RS Prof DR RD Kandou dari bulan Januari - Juli 2009. Kriteria inklusi adalah bayi yang dilahirkan di RS Prof. R.D. Kandou yang memiliki faktor risiko sepsis. Faktor risiko sepsis apabila terdapat dua faktor risiko mayor atau satu faktor risiko mayor dengan dua faktor risiko minor. Diagnosis sepsis ditegakkan berdasarkan adanya gejala klinis dan faktor risiko sepsis serta pemeriksaan laboratorium. Data dievaluasi dengan Pearson chi-square dan Fisher's exact test, dianalisis dengan SPSS 17. Dikatakan berhubungan signifikan antara faktor risiko dengan sepsis bila $\mathrm{p}<0,05$.

Hasil. Dari 72 kasus bayi dengan faktor risiko sepsis, 58 bayi didiagnosis sepsis. Hanya ketuban pecah dini $>18$ jam yang merupakan salah satu faktor risiko mayor berhubungan signifikan dengan sepsis $(\mathrm{p}=0,002$, IK95\% 1,2 4;1,59). Faktor risiko mayor lain yaitu demam intrapartum $>38^{\circ} \mathrm{C}$, korioamnionitis, ketuban berbau, denyut jantung janin $>160 \mathrm{x} /$ menit dan faktor risiko minor yang meliputi ketuban pecah dini $>12$ jam, demam intrapartum $>37,5^{\circ} \mathrm{C}$, skor APGAR rendah, bayi berat lahir sangat rendah, kembar, usia kehamilan $<37$ minggu, keputihan, infeksi saluran kemih tidak berhubungan dengan sepsis.

Kesimpulan. Ketuban pecah dini $>18$ jam berhubungan dengan sepsis awitan dini.

Sari Pediatri 2010;12(4):265-9.
\end{abstract}

Kata kunci: sepsis awitan dini, faktor risiko, neonatus

epsis neonatorum merupakan salah satu penyebab tersering kematian pada neonatus. ${ }^{1-3}$ Kurang lebih $20 \%$ neonatus menderita sepsis dan hal ini menyebabkan 30\%-50\% total kematian neonatus pada negara berkembang. ${ }^{1}$ Sepsis

\footnotetext{
Alamat korespondensi:

Dr. Rocky Wilar, Sp.A, Bagian Ilmu Kesehatan Anak FK UNSRAT/RSU Prof. Dr. R.D. Kandou Manado. Telepon: (0431) 821652; Fax.: (0431) 859091. Rumah: Jalan Unsrat I No.2 Manado. E-mail: rocky_wilar@ yahoo.com
}

neonatorum merupakan istilah yang sering digunakan untuk mendeskripsikan respons sistemik terhadap infeksi pada bayi baru lahir. ${ }^{4}$

Sepsis neonatorum merupakan suatu sindrom klinis bakteremia yang ditandai dengan gejala dan tanda sistemik terutama pada bulan pertama kehidupan. Dari awitan gejala, sepsis neonatorum dibedakan menjadi dua jenis yaitu sepsis awitan dini (SAD) timbul dalam 72 jam pertama kehidupan dan sepsis awitan lanjut (SAL) timbul setelah umur 72 jam. ${ }^{1}$ Sepsis awitan 
dini timbul pada jam pertama kehidupan, $90 \%$ gejala pada bayi timbul dalam 24 jam pertama. ${ }^{5}$ Gejala pada sebagian besar bayi meliputi distres pernapasan atau demam pada 12 jam setelah lahir, ${ }^{6}$ Sedangkan koagulasi intravaskular diseminata dan trombositopeni merupakan komplikasi tersering dari sepsis. ${ }^{5}$

Insidens sepsis neonatorum di negara berkembang masih tinggi, 1,8-18/1000 kelahiran dibandingkan dengan negara maju, 1-5/1000 kelahiran, dengan angka kematian 5\%-20\%., ${ }^{3,5,-9}$ Berdasarkan data tahun 2000 di Nepal, 23\% kematian neonatus disebabkan oleh sepsis. Selain itu, Jain $\mathrm{dkk}^{1}$ menyatakan bahwa faktor risiko yang paling berhubungan dengan sepsis neonatorum adalah prematuritas dan bayi berat lahir sangat rendah (BBLSR). Demikian pula di Alaska, kematian karena sepsis neonatorum paling sering disebabkan oleh prematuritas dan BBLSR. ${ }^{10}$ Di Inggris, kematian pada BBLSR dengan infeksi SAD mencapai $40 \%$, tiga kali lebih tinggi dibandingkan bayi dengan usia kehamilan yang sama tanpa infeksi. ${ }^{6}$ Di Rumah sakit Dr. Cipto Mangunkusumo, Jakarta, insidens sepsis neonatorum masih tinggi mencapai $13,7 \%$ dengan angka kematian 14\%. Pada BBLSR kejadian SAD terjadi pada 26/1000 kelahiran demikian pula pada bayi prematur. ${ }^{7}$

Diagnosis dini sepsis merupakan faktor penentu dalam keberhasilan tata lakana sepsis neonatorum. ${ }^{7}$ Oleh karena itu, suatu penelitian dibutuhkan untuk mengidentifikasi faktor risiko potensial yang sering timbul pada SAD.

\section{Metode}

Penelitian merupakan studi retrospektif kohort dari semua kasus sepsis awitan dini yang dirawat di RS Prof. DR. R.D. Kandou Manado. Semua kasus dikumpulkan selama bulan Januari - Juli 2009 dari data rekam medik termasuk umur, jenis kelamin, lama perawatan, berat lahir, panjang lahir, dan faktor risiko terjadinya sepsis.
Kriteria inklusi adalah bayi yang dilahirkan di RS Prof. DR. R.D. Kandou yang memiliki faktor risiko sepsis. Sedangkan kriteria eksklusi adalah data rekam medik yang tidak lengkap, terdapat kelainan kongenital mayor, pemeriksaan laboratorium tidak lengkap.

Faktor risiko sepsis meliputi faktor risiko mayor yaitu ketuban pecah dini (KPD) $>18$ jam, ibu demam intrapartum $>38^{\circ} \mathrm{C}$, korioamnionitis, ketuban berbau, denyut jantung janin $(\mathrm{DJJ})>160 \mathrm{x} /$ menit. Faktor risiko minor terdiri dari KPD $>12 \mathrm{jam}$, demam intrapartum $>37,5^{\circ} \mathrm{C}$, skor APGAR rendah (menit 1 skor $<5$ dan menit 5 skor $<7$ ), BBLSR (<1500 gram), kembar, usia kehamilan $<37$ minggu, keputihan yang tidak diobati, ibu yang dicurigai infeksi saluran kemih (ISK). Seorang bayi memiliki risiko sepsis bila memenuhi dua kriteria mayor atau satu kriteria mayor ditambah dua kriteria minor.

Sepsis didiagnosis berdasarkan adanya gejala klinis seperti letargi, refleks hisap menurun, merintih, iritabel, kejang, terdapat gangguan kardiovaskular, gangguan hematologik, gangguan gastrointestinal, gangguan respirasi, waktu pengosongan lambung memanjang, dan pemeriksaan laboratorium seperti $\mathrm{CRP}>10 \mathrm{mg} / \mathrm{L}$, IT ratio $\geq 0,25$, leukosit $<5000 / \mu \mathrm{L}$ atau $>30.000 / \mu \mathrm{L}$, trombosit $<100.000 / \mu \mathrm{L}$ dengan atau tanpa biakan darah positif. Data yang didapat dianalisis dengan Pearson chi-square dan Fisher's exact test menggunakan perangkat lunak SPSS 17. Dikatakan berhubungan signifikan antara faktor risiko dengan sepsis apabila $\mathrm{p}<0,05$.

\section{Hasil}

Pada Januari-Juli 2009 terdapat 72 bayi yang lahir dengan faktor risiko sepsis dan 58 bayi didiagnosis sepsis SAD. Dari semua faktor risiko mayor dan minor, hanya KPD >18 jam yang berhubungan signifikan dengan sepsis (RR 1,41, IK95\% 1,24;1,59, $\mathrm{p}=0,002$ ) (Tabel 1 dan 2).

Tabel 1. Faktor risiko mayor pada potensial sepsis awitan dini

\begin{tabular}{lccc}
\hline Faktor risiko mayor & RR & p & IK 95\% \\
\hline Ketuban pecah dini $>18$ jam & 1,41 & 0,002 & $1,24-1,59$ \\
Demam intrapartum $>38^{\circ} \mathrm{C}$ & 0,81 & 0,113 & $0,71-0,90$ \\
Korioamnionitis & 1,27 & 0,259 & $1,13-1,40$ \\
Ketuban berbau & 1,09 & 0,481 & $1,02-1,16$ \\
Denyut jantung janin $>160 x /$ menit & 0,89 & 0,342 & $0,82-0,96$ \\
\hline
\end{tabular}


Tabel 2. Faktor risiko minor pada potensial sepsis awitan dini

\begin{tabular}{lccc}
\hline Faktor risiko minor & RR & P & CI 95\% \\
Ketuban pecah dini $>12$ jam & 0,97 & 0,538 & $0,94-1,01$ \\
Demam intrapartum $>37,5^{\circ} \mathrm{C}$ & 1,02 & 0,638 & $0,99-1,05$ \\
Skor APGAR rendah & 1,09 & 0,477 & $1,02-1,16$ \\
BBLSR & 1,28 & 0,160 & $1,14-1,42$ \\
Usia kehamilan $<37$ minggu & 1,09 & 0,361 & $1,02-1,17$ \\
Kembar & 1,25 & 0,806 & $1,12-1,37$ \\
Keputihan & 1,01 & 0,908 & $0,99-1,04$ \\
Infeksi saluran kemih & 0,82 & 0,159 & $0,73-0,91$ \\
\hline
\end{tabular}

\section{Pembahasan}

Sepsis neonatorum merupakan salah satu penyebab tersering rawat inap pada neonatus. ${ }^{1,11,12}$ Penelitian kami bertujuan menganalisis faktor risiko sepsis dari bayi yang dilahirkan di RS. DR.Prof.R.D.Kandou, Manado selama bulan Januari-Juli 2009. Sepsis merupakan penyebab tersering kematian baik di negara berkembang maupun negara maju yang disebabkan oleh keterlambatan diagnosis dan terapi dengan antibiotik yang sesuai. ${ }^{11}$ Pada tahun 1990 an, perbaikan di unit perawatan intensif neonatus (NICU) dapat menurunkan angka kesakitan dan kematian yang disebabkan oleh SAD pada bayi cukup bulan. ${ }^{5}$

Di antara 72 kasus dengan faktor risiko sepsis, 58 $(80,6 \%)$ bayi di antaranya secara klinis, laboratorium, dan faktor risiko dinyatakan positif sepsis. Sepsis juga didiagnosis apabila terdapat respons sistemik terhadap infeksi tertentu. ${ }^{4}$ Sepsis banyak ditemukan pada bayi kecil terutama prematur yang mempunyai manifestasi klinis sering tidak jelas. ${ }^{8}$ Sepsis dapat mencakup beberapa infeksi sistemik neonatus seperti meningitis, pneumonia, osteomielitis artritis dan ISK. ${ }^{1}$ Pada bayi dengan sepsis terjadi imunosupresi sehingga tubuh tidak mampu untuk mengatasi infeksi sehingga dapat terjadi infeksi nosokomial. ${ }^{13}$

Sebagian besar komplikasi obstetrik pre dan intrapartum berhubungan dengan peningkatan risiko infeksi pada neonatus di antaranya kehamilan kurang bulan, KPD, inersia uteri dengan ekstrasi forcep tinggi, dan demam intrapartum. Infeksi yang bermanifestasi pada awal minggu pertama kehidupan pada umumnya berhubungan dengan mikroorganisme yang ditularkan dari ibu kepada janinnya dan memiliki epidemiologi yang berbeda dengan infeksi yang didapat setelah periode neonatus. ${ }^{4}$

Karakteristik ibu dan janin yang berhubungan dengan SAD telah sering diteliti. Faktor ibu meliputi demam intrapartum $>37,5^{\circ} \mathrm{C}$, korioamnionitis, dan $\mathrm{KPD}>18$ jam. ${ }^{5}$ Faktor risiko neonatus meliputi usia gestasi <37 minggu dan BBLSR., ${ }^{5,10,14}$ Pada penelitian ini, dari semua faktor risiko hanya KPD >18 jam yang merupakan salah satu dari faktor risiko mayor yang berhubungan signifikan dengan sepsis (RR 1,41, IK95\% 1,24;1,59).

Sedangkan demam intrapartum $>38^{\circ} \mathrm{C}$ dan ISK memiliki nilai RR rendah yakni 0,81 (IK95\% $0,71 ; 0,90)$ dan 0,82 (IK95\% 0,73;0,91). Hal ini mungkin disebabkan karena pada ibu demam $>38^{\circ} \mathrm{C}$ dan ISK selalu diberi antibiotik sehingga risiko terjadi sepsis pada janin menurun. Lain halnya dengan $\mathrm{DJJ}>160 \mathrm{x} /$ menit yang memiliki $\mathrm{RR}=0,89(95 \%$ $\mathrm{CI}=0,82-0,96)$. Hal ini bisa merupakan bias. Denyut jantung janin yang meningkat merupakan indikator stres pada janin. Di lain pihak, sepsis bukan satusatunya penyebab stress pada janin. Plasenta previa, abrasio plasenta, partus lama atau partus tidak maju dapat pula menyebabkan stress pada janin.

Insidens SAD sepuluh kali lebih tinggi pada BBLSR dibanding bayi berat lahir normal., ${ }^{50}$ Semakin rendah berat badan lahir semakin tinggi risiko sepsis, 10\% bayi dengan berat lahir antara 1000 dan 1500 gram sering menyebabkan sepsis, $35 \%$ bayi dengan berat lahir $<1000$, gram dan $50 \%$ bayi berat lahir $<750$ gram. ${ }^{15}$ Faktor risiko infeksi Grup B Streptokokus (GBS) awitan dini pada bayi prematur disebabkan oleh infeksi GBS pada ibu, yang dapat terjadi pada vagina ibu atau urin selama kehamilan yang menyebaban ibu demam intrapatum dan KPD. ${ }^{6}$

Berat lahir, usia kehamilan dan skor APGAR sering mempengaruhi angka kesakitan pada bayi. ${ }^{4}$ Tingginya angka kematian pada neonatus masih sering disebabkan oleh infeksi terutama pada bayi prematur dan BBLSR. ${ }^{1}$ Infeksi prenatal dapat mempresipitasi kelahiran prematur dan dapat terjadi kegagalan fungsi imunologi pada bayi prematur sehingga menyebabkan 
infeksi nosokomial dan idiopatik. ${ }^{10}$ Bayi prematur berisiko tinggi terkena SAD disertai sekuele di kemudian hari. ${ }^{5}$

Selama kehamilan sampai ketuban pecah, janin terlindungi dari mikroorganisme flora normal dari ibu oleh selaput ketuban, plasenta dan faktor antibakterial, dari cairan ketuban. Mikroorganisme patogen dapat mencapai janin atau bayi baru lahir melalui berbagai cara yang dapat menyebabkan infeksi. Beberapa prosedur terhadap uterus seperti amniosintesis, pemeriksaan vili korionik transervikal, atau pengambilan darah perkutaneus dapat menyebabkan masuknya organisme melalui kulit atau vagina sehingga terjadi amnionitis dan infeksi janin sekunder. Infeksi pada ibu pada saat melahirkan, terutama infeksi genital merupakan jalur penting transmisi maternal dan berperan penting dalam timbulnya infeksi pada neonatus. Kolonisasi awal pada neonatus pada umumnya apabila terjadi ketuban pecah. Pada beberapa kasus, kolonisasi mikroflora terjadi pada saat proses persalinan. Jika KPD > 24 jam bakteri vagina dapat naik dan pada beberapa kasus menyebabkan inflamasi membran janin, tali pusat, dan plasenta. ${ }^{4}$

Sepsis awitan dini sering didiagnosis di NICU. ${ }^{16}$ Gejala klinis spesifik dapat berupa gangguan respirasi (henti napas, distres pernapasan, ketergantungan oksigen), gangguan sirkulasi (takikardi, bradikardi, sirkulasi yang buruk, hipotensi), gangguan susunan saraf pusat (hipotonia, letargi, iritabilitas, kejang), gangguan gastrointestinal (gangguan reflek menelan, muntah, aspirasi, distensi abdomen, hepatomegali, ileus), suhu tidak stabil (demam, hipotermi), dan ikterus patologis. ${ }^{6,9,12,16,17}$ Penegakan diagnosis memerlukan waktu dan pemeriksaan diagnostik digunakan untuk menentukan status infeksi. ${ }^{4}$ Diagnosis dapat sulit dan terlambat ditegakkan terutama jika ibu telah mendapatkan antibiotik intrapartum. ${ }^{6}$ Pemeriksaan laboratorium tunggal atau kombinasi bersama dengan penemuan faktor risiko dan atau tanda klinis dapat mendiagnosis sepsis neonatorum. ${ }^{4}$

Pemeriksaan laboratorium neonatus tersangka SAD terdiri dari darah perifer lengkap, hitung jenis, dan biakan darah. ${ }^{5}$ Pada umumnya ditemukan peningkatan leukosit yang didominasi oleh sel PMN, penurunan leukosit $(<5000 / \mu \mathrm{L})$, leukositosis $(>30.000 / \mu \mathrm{L})$ trombositopeni $(<100.000 / \mu \mathrm{L})$, dan neutropeni absolut $(\mathrm{PMN}<1500) .5,7$ Sampai saat ini, biakan darah masih merupakan baku emas untuk mendiagnosis sepsis neonatorum namun hasilnya baru didapatkan setelah 2-5 hari. ${ }^{7}$
Saat ini beberapa peneliti berpendapat bahwa adanya satu tanda klinis yang sesuai dengan infeksi disertai nilai $C$-reactive protein $(\mathrm{CRP})>10 \mathrm{mg} / \mathrm{L}$ cukup untuk menegakkan diagnosis SAD dan SAL pada sepsis neonatorum. ${ }^{4}$ Sebaliknya, untuk menentukan kriteria standar yang seragam pada sepsis, beberapa peneliti menggabungkan antara nilai $\mathrm{CRP}>10 \mathrm{mg} / \mathrm{L}$ dengan rasio neutrofil imatur terhadap netrofil total (IT ratio) $\geq 0,25$ sebagai kriteria untuk pemberian antibiotik meskipun belum ditemukan gejala sepsis. ${ }^{4}$

Philip dan Mills merekomendasi pada semua bayi dengan nilai CRP $>10 \mathrm{mg} / \mathrm{L}$ yang disertai satu/lebih gejala klinis atau satu/lebih faktor risiko infeksi harus merupakan pedoman rawat inap neonatus ke NICU dan memulai terapi antibiotik. Chiesa $\mathrm{dkk},{ }^{4}$ juga menggunakan kriteria nilai CRP $>10 \mathrm{mg} / \mathrm{l}$ disertai satu/ lebih gejala klinis kearah infeksi untuk mendiagnosis sepsis di NICU.

Studi epidemiologi infeksi neonatus membagi sepsis menjadi infeksi SAD dan SAL berdasarkan awitan gejala dengan anggapan bahwa infeksi SAD ditularkan perinatal dari ibunya, sedangkan SAL didapatkan pascanatal dari lingkungan. ${ }^{4,18}$ Pada beberapa studi, coagulase-negative Staphylococcus sp (CONS) merupakan penyebab tersering $S A D$, sedangkan pada studi lain group B Streptococcus sp (GBS) dan organisme Gram negatif (Escherichiae coli dan Klebsiella) merupakan patogen dominan tersering. ${ }^{7,8,14}$

Prognosis dari infeksi neonatorum dapat diperbaiki apabila penyakit dapat diketahui lebih awal sehingga antibiotik yang sesuai dapat diberikan. ${ }^{11}$ Penggunaan strategi pencegahan seperti antibiotik intrapartum profilaksis dan terapi empirik awal pada bayi yang terinfeksi dapat mengurangi insidens dan beratnya komplikasi. ${ }^{6}$

Di antara 13 faktor risiko sepsis awitan dini yang dianalisis, hanya ketuban pecah dini $>18$ jam yang berhubungan signifikan dengan sepsis awitan dini. Faktor risiko yang lain tidak berhubungan signifikan dengan sepsis awitan dini karena jumlah sampel yang kurang besar. Penelitian lebih lanjut dengan besar sampel yang lebih besar dibutuhkan untuk mengevaluasi faktor risiko sepsis lainnya.

\section{Daftar pustaka}

1. Jain NK, Jain VM, Maheshwari S. Clinical profile of neonatal sepsis. Kathmandu Univ Med J 2003;1:117-20. 
2. Lawn JE, Ketende KW, Cousens SN. Estimating the causes of four million neonatal deaths in the year 2000 . Int J Epidemiol 2006;35:706-18.

3. Escobar GJ, Li D, Armstrong MA, Gardner MN, Folck BF, Verdi JE, dkk. Neonatal sepsis workups in infants $>2000$ grams at birth: a population-based study. Pediatrics 2000;106:256-63.

4. Chiesa C, Panero A, Osborn JF, Simonetti AF, Pacifico L. Diagnosis of neonatal sepsis: a clinical and laboratory challenge. Clin Chem 2004;50:279-87.

5. Puopolo KM. Bacterial and fungal infections. Dalam: Cloherty JP, Eichenwald EC, Stark AR. Manual of neonatal care. Edisi ke-6. Philadelphia: Lippincott Williams \& Wilkins; 2008.h.274-87.

6. McGuire W, Clerihew L, Fowlie PW. Infection in the preterm infant. BMJ 2004;329:1277-8.

7. Aminullah A. Sepsis pada bayi baru lahir. Dalam: Kosim MS, Yunanto A, Dewi R, Sarosa GI, Usman A. Buku ajar neonatologi. Edisi ke-1.Jakarta: Badan Penerbit IDAI; 2008.h.170-85.

8. Torkaman M, Afsharpaiman S H, Hoseini M J, Moradi M, Mazraati A, Amirsalari S, dkk. Platelet count and neonatal sepsis: a high prevalence of enterobacter spp. Singapore Med J 2009;50:482-5.

9. Escobar GJ. The neonatal "sepsis work-up": personal reflections on the development of an evidence-based approach toward newborn infections in a managed care organization. Pediatrics 1999;103:360-72.

10. Gessner BD, Castrodale L, Gabarro MS. Aetiologies and risk factors for neonatal sepsis and pneumonia mortality among Alaskan infants. Epidemiol Infect 2005;133:87781.

11. Mosayebi Z, Movahedian AH, Moniri R. Profile of bacterial sepsis in neonates from Kashan in iran. J Infect Dis Antimicrob Agents 2003;20:97-102.

12. Lehman, Christopher M. Sepsis in newborns - neonatal sepsis. The physician's guide to laboratory test selection and interpretation. Utah: Arup Laboratories 2006;1-4.

13. Hotchkiss RS, Karl IE. The pathophysiology and treatment of sepsis. N Engl J Med 2003;348:138-50.

14. Mullany LC, Darmstadt GL, Katz J, Khatry SK, LeClerq SC, Adhikari RK, dkk. Risk factors for umbilical cord infection among newborns of Southern Nepal. Am J Epidemiol 2007;165:203-11.

15. Kaufman D, Fairchild KD. Clinical microbiology of bacterial and fungal sepsis in very low birth weight infants. Clin Microbiol Rev 2004;17:638-80.

16. Bender L, Thaarup J, Varming K, Krarup H, Eriksen SE, Ebbesen F. Early and late markers for the detection of early-onset neonatal sepsis. Dan Med Bull 2008;55:21923.

17. Healy CM, Palazzi DL, Edwards MS, Campbell JR, Baker CJ. Features of invasive staphylococcal disease in neonates. Pediatrics 2004;114:953-61.

18. Metzger AM, Barzilai A, Keller N, Kuint J. Are the "good old" antibiotics still appropriate for early-onset neonatal sepsis? a ten year survey. Isr Med Assac J 2009;11:138-42. 